\title{
Impact of Interest Rate Deregulation on Gross Domestic Savings in Nigeria
}

\author{
Mathias A. Chuba \\ Department of Economics, Achievers University Owo, Km 1, Idasen-Ute Road, P. M. B. 1030, Ondo State, Nigeria
}

\begin{abstract}
Nigeria embarked on interest rate deregulation in August, 1987 in order to increase gross domestic savings through an increase in interest rate. The results of previous studies with respect to the impact of interest rate deregulation on gross domestic savings in Nigeria are mixed. This paper argues that interest rate deregulation does not have positive impact on gross domestic savings in Nigeria because savings depends on income rather than interest rate. The main objective of this paper is to determine the impact of interest rate deregulation on gross domestic savings in Nigeria from 1970-2019 using a dummy variable regression technique. The result of the investigation indicates that interest rate deregulation has an insignificant negative impact on gross domestic savings in Nigeria. The gross domestic product has a significant positive relationship with gross domestic savings in Nigeria. The Keynesian proposition that savings are mainly determined by income rather than interest rate is applicable in Nigeria. The classical theory of interest rate and the theory of high interest rate policy that was popularized by McKinnon (1973) and Shaw (1973) are not applicable in Nigeria. The target of economic policy should be gross domestic product and not interest rate because naturally gross domestic saving will increase if gross domestic product increases in Nigeria.
\end{abstract}

Keywords: Deregulation, Interest Rate, Savings, Dummy Variable Regression Model, Nigeria

JEL Classification: C01, E21, E43

\section{INTRODUCTION}

$\mathrm{I}$ n classical view, the interest rate is the incentive for saving. That is, by saving now, individuals can earn interest and accumulate larger sums of money to spend in the future. When the interest rate rises, the incentive to save increases and so the quantity of saving increases. When the interest rate declines, the incentive to save declines and so the quantity of saving declines (Amacher and Ulbrich, 1986). McKinnon (1973) and Shaw (1973) are in support of the classical view because they argue that high interest rate increases savings and interest rate falls when savings increases, thereby induces greater investment. On the other hand, Keynes (1936) believes that savings is mainly determined by income rather than interest rate. This paper argues that an increase in interest rate cannot bring about an increase in savings if it is not accompanied by an increase in income. Savings reduces when income is falling even though the interest rate is rising. The households will increase savings when their incomes are rising in order to accumulate money for investment, retirement, inheritance and unforeseen contingencies even though the interest rate is falling. In other words, savings depends on income rather than interest rate.

The low levels of absolute savings as well as growth rate of savings, made Nigeria to embark on interest rate deregulation in August, 1987. The objective was to increase gross domestic savings through an increase in interest rate as the low level of nominal interest rate from 1970-1986 has discouraged savings mobilization. The available data in Nigeria shows that gross domestic savings is negatively related with interest rate. For example, the nominal deposit interest rate increases from a low level of 5.72 percent in 1981 to 13.09 percent in 1987 and 23.24 percent in 1993. The nominal deposit interest rate decreases from 23.24 percent in 1993 to 16.67 percent in 2002 and 8.90 percent in 2019. The gross domestic savings increases continuously from $\$ 123.136$ billion in1981 to $\$ 137.480$ billion in 1987 , $\$ 639.929$ billion in 1993 , $\$ 3913.570$ billion in 2002 and $\$ 30037.400$ billion in 2019 . Similarly, the gross domestic product increases continuously from $\$ 139.311$ billion in 1981 to $\$ 244.680$ billion in 1987 , $\$ 1257.170$ billion in 1993, $\$ 11501.500$ billion in 2002 and $\$ 145639$ billion in 2019 (WDI, 2020). The gross domestic savings increases even when the nominal deposit interest rate decreases from 1993 to 2019. There is a symbiotic relationship between gross domestic savings and gross domestic product. The available data in Nigeria are in support of the Keynesian view and not the classical view.

There are previous studies on the impact of financial system deregulation on gross domestic savings in Nigeria. The results of the previous studies on the impact of financial system deregulation on gross domestic savings in Nigeria are mixed. For example, the study by Soyibo and Adekanye (1992) indicates that financial system deregulation has an insignificant negative impact on savings mobilization in Nigeria. The study by Udude (2015) shows that interest rate deregulation has a positive impact on savings in Nigeria. The studies by Simon-Oke and Jolaosho (2013) and Onwumere, Okore and Ibe (2012) indicate that interest rate deregulation has a negative impact on savings in Nigeria. Soyibo and Adekanye's study conceals the impact of interest rate deregulation on savings mobilization in Nigeria and the simple ordinary least squares (OLS) regression and vector autoregressive (VAR) models employed in previous studies are inappropriate for an impact study. The simple OLS regression and VAR models are useful in determining the cause and effect relationships among variables. 
In view of the above statement of the problem, this study is guided by the following research question. What is the impact of interest rate deregulation on gross domestic savings in Nigeria? The main objective of this paper is to determine the impact of interest rate deregulation on gross domestic savings in Nigeria. The hypothesis to be tested in this study is that the parameters of the dummy variable regression model are stable for the entire data set, i.e. interest rate deregulation has no impact on gross domestic savings in Nigeria.

This study is significant because of the followings reasons. It reveals that the shift from interest rate regulation to interest rate deregulation leads to an increase in deposit interest rate and the increase in deposit interest rate has an insignificant negative impact on gross domestic savings in Nigeria. It confirms the Keynesian proposition that savings is mainly determined by income rather than interest rate. It demonstrates that the classical theory of interest rate and the theory of high interest rate policy that was popularized by McKinnon (1973) and Shaw (1973) are not applicable in Nigeria. It reveals that the target of economic policy should be gross domestic product and not interest rate because naturally gross domestic saving will increase if gross domestic product increases in Nigeria.

This paper consists of five sections. The next section is literature review. Section 3 presents the methodology. The results are discussed in section 4 , conclusions relevant to research findings are drawn in section 5 and section 6 suggests areas for further studies.

\section{LITERATURE REVIEW}

In classical view, the interest rate is the incentive for saving. That is, by saving now, individuals can earn interest and accumulate larger sums of money to spend in the future. When the interest rate rises, the incentive to save increases and so the quantity of saving increases. When the interest rate declines, the incentive to save declines and so the quantity of saving declines (Amacher and Ulbrich, 1986).

The theory of high interest rate policy was popularized by McKinnon (1973) and Shaw (1973) who argued that, in countries characterized by "financial repression", raising nominal interest rates relative to inflation would increase savings and the supply of investable resources in an economy. According to McKinnon and Shaw, financial repression arises when a country imposes ceilings on nominal deposit and lending interest rates at a low level relative to inflation. The resulting low or negative real interest rates discourage savings mobilization and the channeling of the mobilized savings through the financial system.

Keynes propounded the fundamental psychological law of consumption which forms the basis of the consumption function. He wrote, "The fundamental psychological law upon which we are entitled to depend with great confidence both a prior from our knowledge of human nature and from the detailed facts of experience, is that men are disposed as a rule and on the average to increase their consumption as their income increases but not by as much as the increase in their income" (Jhingan, 2003).

This law has three related propositions: (1) When income increases, consumption expenditure also increases but by a smaller amount. The reason is that as income increases, our wants are satisfied side by side, so that the need to spend more on consumer goods diminishes. It does not mean that the consumption expenditure falls with the increase in income. In fact, the consumption expenditure increases with increase in income but less than proportionately. (2) The increased income will be divided in some proportion between consumption expenditure and saving. This follows from the above proposition because when the whole of increased income is not spent on consumption, the remaining is saved. In this way, consumption and saving move together. (3) Increase in income always leads to an increase in both consumption and saving. This means that increased income is unlikely to lead either to fall in consumption or saving than before. This is based on the above proposition because as income increases consumption also increases but by a smaller amount than before which leads to an increase in saving. Thus with increased income both consumption and saving increase (Jhingan, 2003).

Most cross-country empirical studies that include growth rate of income as a determinant of savings report a significant positive effect of growth rate of income on the savings rate. This result is obtained for example by Modigliani (1990) in a large study based on combined cross-country time-series data, performed separately for 21 OECD countries and 85 developing economies. Japelli and Pagano (1994) for OECD countries and Edwards (1994) for both OECD and LDC economies, confirm this finding. The same result arises in cross-country empirical work for developing economies such as those by Collins (1991), Schmidt-Hebbel, Webb and Corsetti (1992). Akinola and Omolade (2013) and Chuba (2021) confirm the strong sensitivity of savings to income in Nigeria.

Both classicists and Keynesians did not explain how inflation affects savings. Inflation as a determinant of savings behavior has generated much controversy in the literatures. Attitudinal responses by individual to inflationary tendencies through unwarranted costliness of certain items generated by a reduction in purchases and oblivious of their future income growth would lead to a rise in savings (Yusuf and Peters, 1984). Inflation when it becomes persistent could be devastating on the savings pattern of individuals. People might be forced by persistent inflation to make an incursion into their savings in order to cushion the "effects" of future price hike (yusuf and Peters). A "runaway" inflation favours always asset holders, such that they would prefer to invest in real estate items - apparently, savings would further be depressed (Yusuf and Peters). An inflationary increase with a concomitant increase in the nominal interest rate erodes the real value of household's wealth thereby reducing savings 
(Aghevli and Boughton, 1990). With a persistent price hike, incomes of most people are inadequate to afford them the basic necessities of life and so savings decreases as inflation accelerates. Arguments surrounding inflation and savings are many and continuous. However, opinions continue to differ. Soyibo and Adekanye (1992) find that inflation has an insignificant negative effect on aggregate savings in Nigeria.

Country and cross-country studies for OECD countries show that savings is not much influenced by interest rates (see Deaton 1992, section 2.2). Edwards (1994) confirms the insensitivity of private savings to the real interest rates for a cross-country sample of OECD and developing countries. In those exceptional cases where a positive response of savings to the interest rate is found (Gupta 1987, Fry 1988), it is quantitatively very small. Increasing evidence for developing countries (Giovannini 1983, 1985; Corbo and Schmidt-Hebbel 1991; Schmidt-Hebbel, Webb and Corsetti 1992) suggests that private savings (or consumption) typically does not respond to the real interest rates. According to Asamoah (2008), the increase in interest rate that accompanied interest rate liberalization leads to an increase in saving in Ghana.

Soyibo and Adekanye (1992) examine financial system regulation, deregulation and savings mobilization in Nigeria from 1971 to 1989 using ordinary least squares (OLS) regression models. In order to determine the impact of financial system deregulation on savings mobilization in Nigeria, a dummy variable was included in their models. It takes a value of one from 1987, and zero otherwise. Their paper reveals that ex post real interest rates has a significant positive relationship with savings. In all the three models estimated, the coefficients of adjusted ex ante real interest rates are negative and statistically insignificant. The regression coefficient of the dummy variable is negative and statistically insignificant implying that financial system deregulation has an insignificant negative impact on savings mobilization in Nigeria.

Onwumere, Okore and Ibe (2012) examine the impact of interest rate liberalization on savings and investment in Nigeria using a simple OLS regression technique from 1976 to 1999. They find that interest rate liberalization has a negative effect on savings and investment in Nigeria.

Simon-Oke and Jolaosho (2013) assess the impact of real interest rate on savings in Nigeria using time series data from 1980 to 2008. They employed VAR model in data analysis. Their study reveals that real interest rate has a negative relationship with savings in Nigeria.

Udude (2015) examines the impact of interest rate on savings in Nigeria from 1981 to 2013 using VAR analysis. The results show that a 1 percent increase in a period lag of deposit interest rate causes 0.1 percent increase in savings and a 1 percent increase in a year period lag of Gross Domestic Product causes 0.04 percent increase in savings. Udude finds that deposit interest rate has a positive relationship with savings in Nigeria.
This study is necessitated because there are gaps in the literature that need to be filled. Soyibo and Adekanye examine the impact of financial system deregulation on saving mobilization in Nigeria. Their study conceals the impact of interest rate deregulation on savings mobilization Nigeria. Financial system deregulation includes removal of regulation that hinders free competition in the supply of goods and services, removal of credit controls, liberalization of international capital flows, deregulation of exchange rates, elimination of barriers for entry into financial industry and deregulation of interest rate. Soyibo and Adekanye did not conduct a separate investigation of the impact of interest rate deregulation on savings mobilization in Nigeria.

The VAR model employed by Simon-Oke and Jolaosho (2013) and Udude (2015) to determine the impact of interest rate on savings in Nigeria is not an appropriate method because VAR model is not suitable for an impact study. The VAR technique is very useful in dealing with multivariable causality. It can be used to determine the relationships among the variables or the effect of one variable on another variable but it cannot be used to evaluate the impact of one variable on another variable. So, they only succeeded in determining the relationship between interest rate and savings but did not evaluate the impact of interest rate on savings in Nigeria which is the main objective of their studies.

The simple OLS regression technique utilized by Onwumere, Okore and Ibe (2012) to evaluate the impact of interest rate liberalization on savings and investment in Nigeria is not an appropriate method because a simple OLS regression technique is not suitable for an impact study. The simple OLS regression technique is useful in determining the relationship between one variable and another variable or in determining the effect of one variable on another variable but it cannot be used to evaluate the impact of one variable on another variable. Thus, they only succeeded in determining the relationships between interest rate and savings and between interest rate and investment but they did not evaluate the impact of interest rate liberalization on savings and investment in Nigeria which is the main objective of their study.

\section{METHODOLOGY}

\subsection{Theoretical Framework of the Study}

The theoretical framework of the study is the classical theory of interest rate and the theory of high interest rate policy that was popularized by McKinnon (1973) and Shaw (1973). In classical view, the interest rate is the incentive for saving. That is, by saving now, individuals can earn interest and accumulate larger sums of money to spend in the future. When the interest rate rises, the incentive to save increases and so the quantity of saving increases. When the interest rate declines, the incentive to save declines and so the quantity of saving declines (Amacher and Ulbrich, 1986). McKinnon and Shaw argue that, in countries characterized by "financial repression", raising nominal interest rates relative to inflation 
would increase savings and the supply of investable resources in an economy. According to McKinnon and Shaw, financial repression arises when a country imposes ceilings on nominal deposit and lending interest rates at a low level relative to inflation. The resulting low or negative real interest rates discourage savings mobilization and the channeling of the mobilized savings through the financial system.

\subsection{Model Specification}

This study uses a dummy variable regression technique following Soyibo and Adekanye (1992) in determining the impact of financial system regulation and deregulation on savings mobilization in Nigeria. The dummy variable is used for a test of stability of the estimated parameters in a regression equation. The equation (1) below includes both a dummy variable for the intercept and a multiplicative dummy variable for the deposit interest rate. The intercept and the partial slope are allowed to vary, implying different underlying structures for the two conditions ( 0 and 1$)$ associated with the dummy variable. In essence, two different equations are being estimated from the coefficients of a single equation. The impact of interest rate deregulation on gross domestic savings in Nigeria is estimated using a dummy variable regression technique. The dummy variable regression equation is specified as follows:

\section{GDS $=\beta_{0}+\beta_{1}$ DUM $+\beta_{2}$ DIR $+\beta_{3}$ GDP $+\beta_{4} \mathrm{INF}+$ $\beta_{5}(\mathrm{DUM} * \mathrm{INT})+\mathrm{Ut}$

Where GDS is gross domestic savings, DUM is dummy variable, DIR is deposit interest rate, GDP is gross domestic product, INF is inflation, $U_{t}$ is error term, $\beta_{0}$ is intercept, $\beta_{1}$ is differential intercept and $\beta_{5}$ is differential slope coefficient (slope drifter). The specification of the model is based on the theoretical literature discussed in section 2 of this paper. The deposit interest rate and gross domestic product are expected to have a positive relationship with gross domestic savings. The inflation is expected to have a negative relationship with gross domestic savings. The effect of a dummy variable on gross domestic savings may be negative, zero or positive.

The differential intercept indicates how much the intercept of the second period's GDS function (the category that receives the dummy value of 1) differs from that of the first period. The differential slope coefficient indicates how much the slope coefficient of the second period's GDS function (the category that receives the dummy value of 1) differs from that of the first period. Dummy variable $=0$ for observations in 1970-1986 and dummy variable $=1$ for observations in 19872019. While 1 indicates the presence of interest rate deregulation, 0 indicates the absence of interest rate deregulation.

The F-statistic is interpreted following these decisions: if Fcalculated is greater than the F-tabulated, the null hypothesis that the parameters are stable for the entire data set will be rejected and a conclusion that there is evidence of structural instability will be drawn and vice versa. The interpretation of the F-statistic is based on the following assumptions:

$$
\begin{aligned}
& \mathrm{V}_{1}=\mathrm{K}-1 \\
& \mathrm{~V}_{2}=\mathrm{N}-\mathrm{K}
\end{aligned}
$$

Where $V_{1}$ is degree of freedom for numerator, $V_{2}$ is degree of freedom for denominator, $\mathrm{K}$ is number of parameters and $\mathrm{N}$ is number of observations.

\subsection{Estimation Method}

The dummy variable regression equation is estimated using eview 9. The time series properties of the data are analyzed using Phillips-Perron (PP) unit root test of Phillips and Perron (1988). The cointegration test is carried out using the Johansen (1988) maximum likelihood procedure. The dummy variable regression equation is estimated in order to determine the impact of interest rate deregulation on gross domestic savings in Nigeria.

\subsection{Sources and Description of Data}

The empirical analysis is conducted using annual data. The time span covered is 1970 to 2019 . The choice of 1970 as the base year is due to the fact that the civil war in Nigeria ended on $15^{\text {th }}$ January 1970. This paper examines interest rate and savings within the period of post-Nigerian civil war. The choice of 2019 as the terminal year is premised on the fact that the time series data of the variables required for the study are available only up to that year. The data of gross domestic savings from 1970-1985 are obtained from Annual Abstract of Statistics, Federal Office of Statistics, 1995 Edition and The World Bank: World Tables, 1994. The data of gross domestic savings from 1986-2019, the data of deposit interest rate, gross domestic product and inflation from 1970-2019 are obtained from World Development Indicators (WDI), 2020. The data of gross domestic savings and gross domestic product are in Local Currency Unit (LCU), that is, they are in naira. The data of deposit interest rate and inflation, consumer prices are in percentage.

\section{RESULTS AND DISCUSSION}

\subsection{Unit Root Test}

The results of Phillips-Perron unit root test are presented in table 1. All the variables are non-stationary at levels because PP test statistic is less than test critical values in absolute terms and p-value of each variable is greater than 5 percent at 1 percent and 5 percent levels of significance. All the variables are stationary at first differences because PP test statistic is greater than test critical values in absolute terms and p-value of each variable is less than 5 percent at 1 percent, 5 percent and 10 percent levels of significance. The PP test indicates that all the variables are of the same order of integration at 1 percent, 5 percent and 10 percent level of significance. 
Table 1: Results of Phillips-Perron Unit Root Test

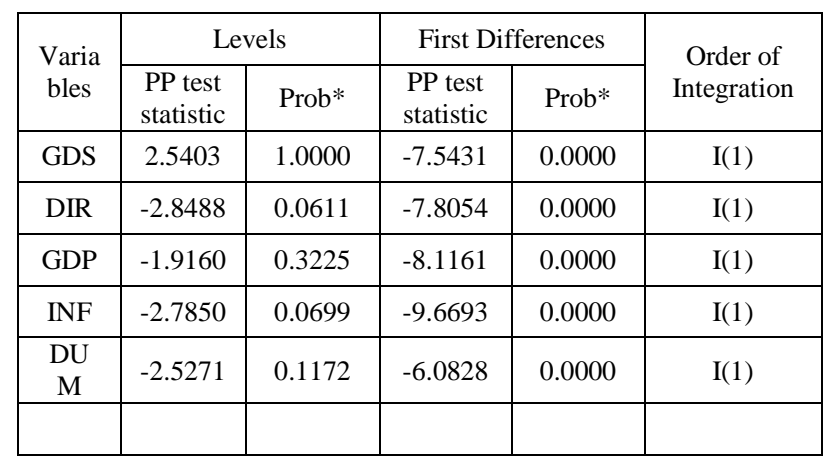

Test critical values: $1 \%$ level -3.6210

$$
\begin{array}{cc}
5 \% \text { level } & -2.9434 \\
10 \% \text { level } & -2.6103
\end{array}
$$

*Mackinnon (1996) one sided p-values

Source: Author's Computation Using E-view 9.

\subsection{Cointegration Test}

The results of Johansen test for cointegrating vectors are presented in table 2. The Trace statistic is greater than 5 percent Critical Value and p-value is less than 5 percent for all except at most 4 hypothesized numbers of cointegrating equations. The Trace test denotes rejection of 5 hypothesized numbers of cointegrating equations at 5 percent level. The Trace test indicates 4 cointegrating equations at the 5 percent level. The Max-Eigen statistic is greater than 5 percent Critical Value and p-value is less than 5 percent for all except at most 1 and at most 4 hypothesized numbers of cointegrating equations. The Maximum Eigenvalue test denotes rejection of 4 hypothesized numbers of cointegrating equations at the 5 percent level. The Maximum Eigenvalue test indicates 1 cointegrating equation at the 5 percent level. Both the Trace and Maximum Eigenvalue tests indicate that all the variables that are used for this study are cointegrated or there is a long-run equilibrium relationship among them.

Table 2: Johansen Test for Cointegrating Vectors

\begin{tabular}{|c|c|c|c|c|c|c|c|}
\hline \multicolumn{2}{|c|}{ Hypothesized No. of CE(s) } & \multicolumn{3}{|c|}{ Trace } & \multicolumn{3}{c|}{ Maximum Eigenvalue } \\
\hline Trace & $\begin{array}{c}\text { Maximum } \\
\text { Eigenvalue }\end{array}$ & Trace Statistic & $\begin{array}{c}0.05 \text { Critical } \\
\text { Value }\end{array}$ & Prob.** & $\begin{array}{c}\text { Max-Eigen } \\
\text { Statistic }\end{array}$ & $\begin{array}{c}\text { 0.05 Critical } \\
\text { Value }\end{array}$ & Prob.** \\
\hline None $*$ & None $*$ & 164.6024 & 95.7537 & 0.0000 & 66.8392 & 40.0776 & 0.0000 \\
\hline At most $1 *$ & At most 1 & 97.7632 & 69.8189 & 0.0001 & 33.1202 & 33.8769 & 0.0614 \\
\hline At most $2 *$ & At most 2* & 64.6431 & 47.8561 & 0.0006 & 30.1150 & 27.5843 & 0.0231 \\
\hline At most 3* & At most 3* & 34.5280 & 29.7971 & 0.0132 & 22.9510 & 21.1316 & 0.0274 \\
\hline At most 4 & At most 4 & 11.5770 & 15.4947 & 0.1784 & 7.5896 & 14.2646 & 0.4220 \\
\hline At most 5* & At most 5* & 3.9874 & 3.8415 & 0.0458 & 3.9874 & 3.8415 & 0.0458 \\
\hline
\end{tabular}

*denotes rejection of the hypothesis at the 0.05 level

** Mackinnon- Haug- Michelis (1999) p-values

Source: Author's Computation Using E-view 9.

\subsection{Dummy Variable Regression Results}

Table 3 presents the dummy variable regression results of gross domestic savings. The calculated F-statistic is 99.5111 . The tabulated F-statistic is 3.51 at 5 percent level of significance and at 5 and 44 degrees of freedom. The calculated F-statistic is greater than the tabulated F-statistic. Therefore, this study rejects the null hypothesis that the parameters are stable for the entire data set and concludes that there is an evidence of structural instability. In other words, the shift from interest rate regulation to interest rate deregulation leads to an increase in deposit interest rate and the increase in deposit interest rate has a negative impact on gross domestic savings in Nigeria. This implies that interest rate deregulation has a negative impact on gross domestic savings in Nigeria.

The differential intercept is $4.87 \mathrm{E}+12$ and its $\mathrm{p}$-value is 0.0488 . The differential slope coefficient is $-1.79 \mathrm{E}+11$ and its $\mathrm{p}$-value is 0.5308. As these regression results show, the differential intercept is statistically significant and differential slope coefficient is statistically insignificant, strongly suggesting that the deposit interest rate-gross domestic savings regressions for the two time periods are different. This is a case of parallel regressions. These results show that the difference in the regressions for the two time periods is because of the differences in the intercept terms.

The regression coefficient of deposit interest rate is $-2.40 \mathrm{E}+10$ and its p-value is 0.9217 . The regression coefficient of deposit interest rate is negative but it is statistically insignificant. This result shows that the shift from interest rate regulation to interest rate deregulation leads to an increase in deposit interest rate and the increase in deposit interest rate has an insignificant negative impact on gross domestic savings in Nigeria. This implies that interest rate deregulation has an insignificant negative impact on gross domestic savings in Nigeria. This result confirms the Keynesian proposition that 
savings is mainly determined by income rather than interest rate. Country and cross-country studies for OECD countries show that savings is not much influenced by interest rates (see Deaton 1992, section 2.2). Edwards (1994) confirms the insensitivity of private savings to the real interest rates for a cross-country sample of OECD and developing countries. Increasing evidence for developing countries (Giovannini 1983, 1985; Corbo and Schmidt-Hebbel 1991; SchmidtHebbel, Webb and Corsetti 1992) suggests that private savings (or consumption) typically does not respond to the real interest rates. The results obtained in this study also corroborate the results of previous researchers in Nigeria. For example, Soyibo and Adekanye (1992) find that financial system deregulation has an insignificant negative impact on savings mobilization in Nigeria. The study by Simon-Oke and Jolaosho (2013) reveals that real interest rate has a negative impact on savings in Nigeria. Onwumere, Okore and Ibe (2012) find that interest rate liberalization has a negative impact on savings and investment in Nigeria.

The regression coefficient of gross domestic product is 0.162682 and its p-value is 0.0000 . This result shows that gross domestic product has a significant positive relationship with gross domestic savings in Nigeria. This result confirms the Keynesian proposition that savings is an increasing function of income. Most cross-country empirical studies that include growth rate of income as a determinant of savings report a significant positive effect of growth rate of income on the savings rate. This result is obtained for example by Modigliani (1990) in a large study based on combined crosscountry time-series data, performed separately for 21 OECD countries and 85 developing economies. Japelli and Pagano (1994) for OECD countries and Edwards (1994) for both OECD and LDC economies, confirm this finding. The same result arises in cross-country empirical work for developing economies - such as those by Collins (1991), SchmidtHebbel, Webb and Corsetti (1992). Akinola and Omolade (2013) and Chuba (2021) confirm the strong sensitivity of savings to income in Nigeria.

The regression coefficient of inflation is $-3.09 \mathrm{E}+10$ and its $\mathrm{p}-$ value is 0.2140 . This result shows that inflation has an insignificant negative relationship with gross domestic savings in Nigeria. An inflationary increase with a concomitant increase in the nominal interest rate erodes the real value of household's wealth thereby reducing savings (Aghevli and Boughton, 1990). Soyibo and Adekanye (1992) find that inflation has an insignificant negative effect on aggregate savings in Nigeria.

The coefficient of determination is 91.88 percent. This implies that 91.88 percent variation in gross domestic savings is explained by deposit interest rate, gross domestic product, inflation and dummy variable; and 8.12 percent variation in gross domestic savings is explained by other factors outside the model. The F-statistic is 99.5111 and p-value of F-statistic is 0.0000 percent. The F-statistic, the overall test of goodness of fit of the regression is statistically significant. The Durbin-
Watson statistic is 1.8206 . The estimated dummy variable regression model is free from autocorrelation because the Durbin-Watson statistic is approximately equal to 2 . The results obtained in this study indicate that there is no omission of important explanatory variable and there is no misspecification of the mathematical form of the model.

Table 3: Dummy Variable Regression Results of Gross Domestic Savings

\begin{tabular}{|c|c|c|c|c|}
\hline Variable & Coefficient & Std Error & $\mathrm{t}$-Statistic & Prob. \\
\hline C & $5.76 \mathrm{E}+11$ & $1.41 \mathrm{E}+12$ & 0.4085 & 0.6849 \\
\hline DUM & $4.87 \mathrm{E}+12$ & $2.40 \mathrm{E}+12$ & 2.0266 & 0.0488 \\
\hline DIR & $-2.40 \mathrm{E}+10$ & $2.43 \mathrm{E}+11$ & -0.0988 & 0.9217 \\
\hline GDP & 0.1627 & 0.0121 & 13.4577 & 0.0000 \\
\hline INF & $-3.09 \mathrm{E}+10$ & $2.45 \mathrm{E}+10$ & -1.2608 & 0.2140 \\
\hline DUM*DIR & $-1.79 \mathrm{E}+11$ & $2.84 \mathrm{E}+11$ & -0.631792 & 0.5308 \\
\hline
\end{tabular}

R-squared: $0.9188 \quad$ F-statistic: 99.5111

Prob(F-statistic): 0.0000 D-W stat: 1.8206

Source: Author's Computation Using E-view 9.

\section{CONCLUSIONS}

The interest rate deregulation has an insignificant negative impact on gross domestic savings in Nigeria. The gross domestic product has a significant positive relationship with gross domestic savings in Nigeria. The Keynesian proposition that savings is mainly determined by income rather than interest rate is applicable in Nigeria. The classical theory of interest rate and the theory of high interest rate policy that was popularized by McKinnon (1973) and Shaw (1973) are not applicable in Nigeria. The target of economic policy should be gross domestic product and not interest rate because naturally gross domestic saving will increase if gross domestic product increases in Nigeria.

\section{SUGGESTIONS FOR FURTHER STUDIES}

1. Future research should examine the impact of interest rate deregulation on gross domestic investment in Nigeria.

2. Future studies should evaluate the impact of interest rate deregulation on economic growth in Nigeria.

\section{REFERENCES}

[1] Aghevli, B. B. and Boughton, J. M. (1990); National Saving and the World Economy: Why have saving rates declined since the early 1970s? Some reasons, and the policy measures needed to stimulate saving, in Finance \& Development, June Edition.

[2] Akinola, G. W. and Omolade, A. (2013); Savings, Gross Capital Formation and Economic Growth Nexus in Nigeria (1975-2008), JOSR Journal of Economics and Finance, 1(2), 19-25.

[3] Amacher, R. C. and Ulbrich, H. H. (1986); Principles of Macroeconomics, South-Western Publishing Co., Cincinnati, Ohio.

[4] Asamoah, G. N. (2008); The Impact of the Financial Sector Reforms on Savings, Investment and Growth of Gross Domestic Product (GDP) in Ghana, International Business and Economic Research Journal, 7(10), 73-84. 
[5] Chuba, M. A. (2021); The Paradox of Thrift: Empirical Evidence in Nigeria, International Journal of Social Science and Human Research, 04(10): 3026-3035.

[6] Collins, S. M. (1991); Saving Behavior in Ten Developing Countries, in B. D. Douglas and J. B. Shoven, (eds): National Saving and Economic Performance. National Bureau of Economic Research, University of Chicago Press.

[7] Corbo, V. and Schmidt-Hebbel, K. (1991); Public Policies and Saving in Developing Countries, Journal of Development Economics, 36: 89-115.

[8] Deaton, A. (1992); Understanding Consumption. Oxford University Press.

[9] Edwards, S. (1994); Why are Latin America's Saving Rates so Low?, Manuscript, presented at the Conference on Growth Prospects in Latin America, Bogota (Colombia), June.

[10] Fry, M. J. (1988); Money, Interest and Banking in Economic Development, John Hopkins University, Baltimore, Maryland.

[11] Giovannini, A. (1983); The Interest Elasticity of Savings in Developing Countries: The Existing Evidence, World Development, 11(7): 601-607.

[12] Giovannini, A. (1985); Saving and the Real Interest Rate in LDCs, Journal of Development Economics, 18(2-3): 197-217.

[13] Gupta, K. L. (1987); Aggregate Savings, Financial Intermediation, and Interest Rate, Review of Economics and Statistics, 69(2): 30311.

[14] Japelli, T and Pagano, M. (1994); Saving, Growth, and Liquidity Constraints, Quarterly Journal of Economics, 106: 83-109.

[15] Jhingan, M. L. (2003); Macro-Economic Theory, $11^{\text {th }}$ Revised and Enlarged Edition, Vrinda Publications (P) Ltd, Delhi.

[16] Johansen, S. (1988); Statistical Analysis of Cointegrating Vectors, Journal of Economic Dynamics and Control, 12: 231-54.

[17] Keynes, J. M. (1936); The General Theory of Employment, Interest and Money, Harcourt, Brace and Co., New work.
[18] McKinnon, R. (1973); Money and Capital in Economic Development, Washington D. C.: Brookings Institution.

[19] Modigliani, F. (1990); Recent Declines in the Saving Rate: A Life Cycle Perspective, Manuscript, Frisch Lecture, Sixth World Congress of the Econometric Society, Barcelona (August).

[20] Onwumere, J. U. J., Okore, A. O. and Ibe, I. G. (2012); The Impact of Interest Rate Liberalization on Savings and Investment: Evidence from Nigeria, Research Journal of Finance and Accounting, 3(10): 130-136.

[21] Phillips, P. C. B. and Perron, P. (1988); Testing for a Unit Root in Time Series Regression, Biometrika, 75(2): 335-346. DOI: 10.1093/biomet/75.2.335.

[22] Schmidt-Hebbel, K.; Webb, S, and Corsetti, G. (1992); Household Saving in Developing Countries: First Cross-Country Evidence, World Bank Economic Review, 6(3): 529-547.

[23] Shaw, E. S. (1973); Financial Deepening in Economic Development, New York: Oxford University Press.

[24] Simon-Oke, O. O. and Jolaosho, O. M. (2013); Real Interest Rate and Savings Mobilization in Nigeria, International Journal of Development and Economic Sustainability, 1(2): 28-40.

[25] Soyibo, A. and Adekanye, F. (1992); Financial System Regulation, Deregulation and Savings Mobilization in Nigeria, African Economic Research Consortium, Research Paper 11, Nairobi, Kenya.

[26] Udude, C. C. (2015); Impact of Interest Rate on Savings on the Nigeria's Economy (1981-2013), Journal of Policy and Development Studies, 9(3): 73-82.

[27] WDI, 2020. The World Bank Data.

[28] Yusuf, S. and Peters, R. K. (1984); Savings Behaviour and its Implication for Domestic Resource Mobilization: The Case of the Republic of Korea, World Bank Staff Working Paper, No. 628, Washington DC: The World Bank. 